GIS - 理論と応用

Theory and Applications of GIS, 2010, Vol.18, No.1, pp.39-50

【原著論文】

\title{
空間基盤データを用いた地下埋設物管理の効率化提案と実証評価
}

\author{
窪田 諭 $*$ 柗村一保 $* *$ 一 一昭吉 $* * *$
}

\section{Proposal and Evaluation of Efficiency for Road Buried Objects Management Using Spatial Data Infrastructure}

\author{
Satoshi KUBOTA*, Kazuyasu MATSUMURA**, and Akiyoshi ICHIUJI***
}

\begin{abstract}
The road buried objects are managed using paper maps and GIS by road administrator. Paper maps are still used for road possession permit application and continuation. It is necessary for road administrator and utility company to cut cost down by using GIS. The objective of this study is to investigate importance of spatial data infrastructure (SDI) shared between the public and private sectors using examples of road possession permit and continuation. The road possession permit and application system was developed using shared SDI. The efficiency method of possession continuation application was proposed, and evaluated with Kadoma city and Osaka Gas Co., Ltd.
\end{abstract}

Keywords: 空間基盤デー夕 (spatial data infrastructure), 道路占用許可 (road possession permit), 地理空間情報の共有（share use of spatial information），業務の効率化（business process reengineering)

\section{1.はじめに}

我が国では，「地理空間情報活用推進基本法」の 施行とそれに伴う基盤地図情報の整備により，国や 地方公共団体が提供する地理情報を活用し，民間企 業の競争力向上，市民自らが情報を作成し発信する ための基盤として地理情報を活用できる環境が整い つつある。また，「地理空間情報に関する地域共同 整備推進ガイドライン」(総務省ほか, 2009)により, 都道府県の広域に抢ける共通の基盤デー夕の利用が 進もうとしている。大阪府域においては，大阪府， 府内市町村およびユーティリティ企業（電力, 通信, ガス）が協働して空間基盤デー夕の整備と更新，活 用（窪田ほか, 2007）に取り組んでいる。そこでは, 道路管理者とユーティリテイ企業が共通に利用でき る空間基盤デー夕を整備し, 道路占用許可申請業務 を電子化する取り組みを推進してきた。

道路管理者は, 管理道路内の電柱, 電線, 水管, 下水道管，ガス管などを占用物として，その位置と 数量を管理し, 数量に基づき占用料を事業者から徵
収している. 道路占用物の申請および継続に関して, 道路管理者は公共測量作業規程に基づく地図を調製 して，道路と関連施設を管理している。そして，占 用事業者（ユーティリティ企業）の申請図書に基づ いて，道路に設置あるいは埋設されている占用物件 の位置管理と, 占用料の徵収のための数量を把握し ている。一方，占用事業者（ユーティリティ企業） は，独自に測量あるいは地方公共団体が作成した地 図を利用して申請図面を作成している。そして，施 工後の完成図書を基に，設備管理図面の作成と修正 を行っている，道路管理者に损ける占用物の管理に は GIS が利用されることが増えてきているが，多 くは紙地図が利用されている。また，占用事業者か ら道路管理者への道路占用許可申請や占用継続など も紙地図によって実施されることが多く, 道路管理 者と占用事業者の双方にとって，GIS を利用して業 務の効率化を図る余地は大きい.

そこで, 本研究では, 道路占用物（特に地下埋設 物）の管理業務を対象として，官民共有の空間基盤

* 正会員 岩手県立大学ソフトウェア情報学部 (Iwate Prefectural University) 干 020-0193 岩手県岩手郡滝沢村滝沢字巣子 152-52 E-mail : s-kubota@iwate-pu.ac.jp

** 正会員 株式会社オージス総研（Osaka Gas Information System Research Institute Co., Ltd.）

*** 非会員 門真市 (Kadoma City) 
デー夕を活用したシステム開発と検証を行い, 実業 務に扮ける空間基盤デー夕の活用の有用性と可能性 について述べる。ここでは, 道路占用許可申請業務 の電子化を実現するために, 官民共有の空間基盤 デー夕を利用した協議・申請システム（窪田ほか, 2005，2007）を概説し，既報システムを用いた社会 実験による評価結果のさらなる分析を行い，考察を 追加する。ささらに, 道路占用許可申請業務の一連の 流れを情報システムによって支援するために, 道路 占用物の継続申請業務を効率化する方法を新たに考 案する。そして, 大阪府門真市において実デー夕に よる実証実験を行い, 考案する方法の有効性を検証 し, 実業務で利用するための運用を提案する。本研 究の実証実験には, 大阪府および府内全市町村の道 路管理担当部署, ユーティリティ企業（電力, 通信, ガス）が参加し, 地下埋設物データの交換・共有を 実業務にて行う。

\section{2. 道路占用に係わる既存の取り組み}

2.1 . 道路占用物管理業務の概要

道路管理者は管理道路内の電柱, 電線, 水管, 下 水道管, ガス管などの地下埋設物デー夕を占用物件 とし，その位置と数量を管理し，数量に基づき占用 料を事業者から徵収する業務を実施する。道路占用 に係わる協議と申請業務は, 以下の流れで行われる. - 道路調整会議：道路管理者と占用者が集合して, 年度初めの大規模計画工事を調整する。

- 埋設物調査 : 占用者が各工事の設計前に, 地下埋 設物を管理する各企業体に対して地下埋設物の有 無を調査する。

·道路法第 34 条協議: 道路の掘り返し低減のため に，企業体間で工事時期を調整する.

- 道路占用許可申請 : 占用者 (申請者) が道路管理 者へ許可申請を行う。道路管理者は, 申請内容を 審査し, 許可書を発行して道路占用を許可する. 道路占用許可申請の内容は, 地方公共団体の道路 占用管理システムに保存されることもある.

- 施工通知：占用者が, 関係する各企業体に工事施 工を通知する。

- 施工協議 : 施工通知を契機に現地の工事協議と調
整を行う。

・施工：埋設物工事を行う。

・継続申請：占用の期間を満了し,さらに継続して 占用し続ける場合に占用継続を申請する。これは, 道路占用物件の許可期間が終了し, 同物件の占用 を継続する場合に，更新の許可を受けるために実 施するものである.

道路占用に係わる協議や申請業務は担当者による 会議や移動を伴い, ともに紙の申請書, 員数調書, 位置図および図面などを用いて地下埋設物などの占 用物情報を交換し共有している。

2. 2. 道路管理センターにおける地下埋設物の管理 政令指定都市においては, 道路管理センターが, 公益事業者が行う道路占用許可申請と道路管理者 が行う占用許可のためのオンライン道路占用許可 申請システムを運用している（佐藤, 2002 ; 馬渡, 2006 ; 東明, 2008)。ここでは, 道路占用許可申請 業務に係わる次の 3 つの業務がシステム化され運用 されている。

·道路・占用物件管理業務

·道路工事調整業務

·道路占用許可申請業務

オンライン道路占用許可申請システムは, 道路占 用に係わる業務 (申請書類作成, 提出, 受付, 許可, 着手, 竣工, 占用料計算, 進渉管理, 集統計, 各種 精算事務など）をオンラインで実施するシステムで ある。たたし，システムは政令指定都市のみを対象 としており，多大な地下埋設物を管理するその他市 町村を対象としていない. また,これらの報告には, 占用物件の継続申請をシステム化している記述は見 あたらない，道路占用継続業務は，電子デー夕を利 用しては実施していないようである.

2. 3. GIS 大縮尺空間データ官民共有化推進協議 会における地下埋設物管理の取り組み

GIS 大縮尺空間データ官民共有化推進協議会にお いては, 道路占用許可申請業務に係わる協議・申請 システムを開発し，実運用に向けて取り組んでいる （窪田ほか, 2005, 2007). 協議・申請システムの概 
要を次章に述べる.

\section{3. 道路占用許可申請に係わるシステムの開発 と評価}

道路占用許可申請業務において, 地下埋設物デー 夕は道路管理者と占用者の間で交換される. 既報(窪 田ほか，2005，2007）では，空間基盤デー夕を地下 埋設物データ交換の基盤として利用し, 道路占用許 可申請業務に係わる協議・申請システムを開発した。 本章では，既報システムを概説し，これを利用して 行った社会実験の結果分析を深め考察を追加する.

3.1. システムの設計と開発

3.1.1. システム概要

道路占用許可申請に係わるシステムは, 道路調整 会議, 道路法第 34 条協議, 道路占用許可申請を対 象とする。本システムは, 協議・申請内容を入力す る文字システムと占用物件を管理する地図システム から構成される。ここでは, 地方公共団体あるいは ユーティリテイ企業で占用物件（地下埋設物）を管 理する既存のバックオフィスシステムを分離する構 成とした。 システムでは標準化できる項目を明確に し, 地方公共団体に扔ける道路占用許可電子申請シ ステムの基本仕様（国土交通省，2003）に準拠して 開発することによって, 各市町村の業務フローに柔 軟に対応できるようにした。 システムには次の特徵 がある。

・クライアント PC からは Web ブラウザのみでシス テムを利用できる。

・占用事業者と道路管理者が地下埋設物デー夕を交 換できるように，システムで扱うデー夕は道路台 帳管理デー夕製品仕様書（国土交通省，2005）に 準拠して XML 形式で標準化される.

- 道路調整会議, 道路法第 34 条協議, 道路占用許 可申請に扮ける占用位置を示すための位置図は, 空間基盤データ上でWebGIS を用いて作成され る. 将来は, 占用物件の位置管理も空間基盤デー 夕上で行えるようにする。

・物件検索と地図表示にWeb サービスを採用する。

・オンライン・ストレージ機能によって図面, 写
真などの大容量ファイルを添付でき, これらを XML データベースで管理する。

・占用物件の数量を記載する員数調書の様式は地方 公共団体毎に異なるため, MS-Excel ベースの様 式ファイルを用意する。利用者はオフラインで員 数調書を作成し, オンラインで添付ファイルとし てシステムに登録する。

・バックオフィスシステム用に G-XML データをダ ウンロードできる.

\section{1. 2. WebGIS}

本システムでは, 位置図としての機能を持つ編集 型の WebGIS を開発した。 WebGIS は位置図と工事 位置の入力, 編集, 閲覽の機能を有し, 空間基盤 データとXML データの整合を図り, GIS と XML データベースが連携して稼働するシステムである. WebGIS に入力, 編集機能を構築することによって, 道路占用許可申請から道路管理業務まで一貫した情 報を流通させることができる，空間基盤デー夕には 数值地図 25000 と大阪府 $2500 \mathrm{DM}$ デー夕を利用し た。

\subsubsection{XML データベース}

道路占用許可申請業務では，一件の申請業務に複 数の協議書, 申請書, 地図, 図面などが添付される. 本システムではこれらを一つの情報として管理する ために，XML データベースを採用した。 申請内容 を閲覧する場合, システムは XML データベースか ら申請内容と関連する図面などの情報と位置情報を 取得する。

\subsection{4. システム構成}

道路占用許可申請に係わるシステムの構成を図 1 に示す。システムはデータの蓄積・検索処理を高速 化し, 利用者の利便性を高めるために, Web サーバ, GIS サーバ，XML サーバの構成とした。システム は占用者毎にレイヤを分類し，他者の占用物件を編 集することができないようにセキュリティを確保し た. Webサーバは, CPUとして Intel Xeon 3.2GHz を2 個, メモリ $2 \mathrm{~GB}$, ハードディスク $72.8 \mathrm{~GB}$ を搭 

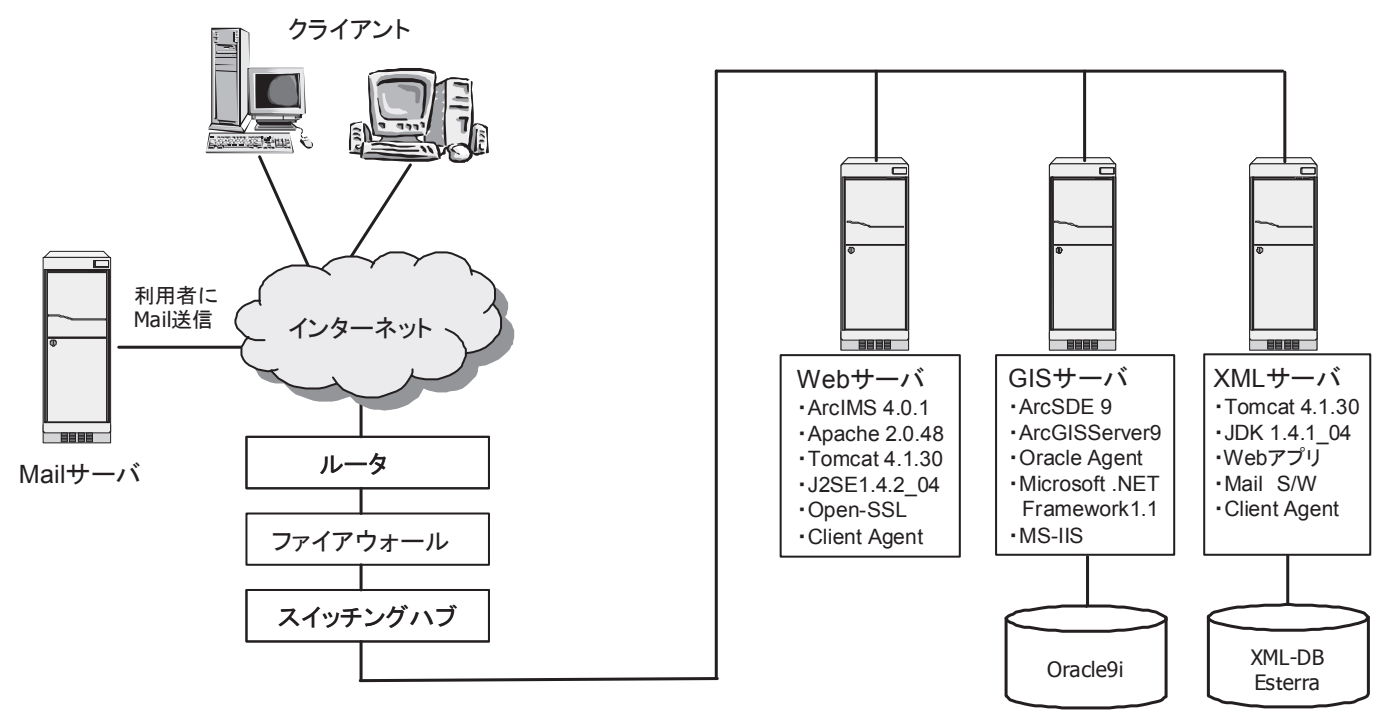

図 1 道路占用許可申請に係わるシステムの構成

載する. GIS サーバは, CPU として Intel Xeon 3.2GHz を2個，メモリ $4 \mathrm{~GB}$ ，ハードディスク $72.8 \mathrm{~GB} を$ 搭載する。XML サーバは, CPU として Intel Xeon $3.2 \mathrm{GHz} 2$ 個, メモリ $2 \mathrm{~GB}$, ハードディスク 146.8GB を搭載する. OS /プラットフォームはサー バ共通で Microsoft Windows 2000 Sever SP4 を導入 し，WebサーバにはJ2SE 1.4.2_04, GIS サーバに は Microsoft .NET Framework 1.1，クライアントには Windows 2000 SP4 以上, Internet Explorer 6.0 以上を 導入した。ミドルウェアとして, Web サーバには Apache 2.0.48, Tomcat 4.1.30, ArcIMS4.0.1 (ESRI 社製), GIS サーバには ArcSDE 9, ArcGIS Server 9（以上，ESRI 社製），Oracle9i， Microsoft Internet Information Server，XML サーバには Tomcat 4.1.30, XML データベース EsTerra（メディアフュージョン 製）を使用した。

\section{2. 社会実験}

\subsection{1. 実験方法}

開発したシステムを大阪府と府内市町の実業務に おいて実証し，その有用性を検証した。

（1）道路調整会議

道路調整会議の実験フィールドは大阪府岸和田土 木事務所管内の府および市町の管理道路とし, 2006 年度予定工事である道路工事抒よび各占用者の占用 工事を対象とした。参加者は岸和田土木事務所, 府
の上下水道部門, 土木事務所管内の市（道路部門, 上下水道部門），ユーティリティ企業である。実験 期間は 2006 年 2 月 27 日〜 3 月 10 日である。その 結果, 協議件数は 135 件あり, 内訳は道路 64 件, 下水道 30 件, 上水道 19 件, 電力模擬デー夕, 通信 11 件，ガス 11 件であった，道路調整会議のシステ 厶利用例を図 2 に示す。図 2 は, 道路調整案件の一 覧と管内全域図における地下埋設物の工事予定が表 示され，拡大すると個別案件の詳細情報を閲覧でき ることを示す。

\section{（2）道路法 34 条協議}

道路法 34 条協議の実証フィールドは堺市, 門真 市, 羽曳野市とし, 参加者は各市の道路部門と上下 水道部門，ユーティリティ企業である。実験期間は 2004 年 8 月 2 日〜 9 月 17 日である。年の結果, 協 議件数は模擬デー夕を含めて 30 件あり, 内訳は道 路 2 件, 下水道 8 件, 上水道 4 件, 電力 5 件, 通信 4 件，ガス 7 件であった。道路法 34 条協議のシス テム利用例を図 3 に示す。図 3 は, 個別の協議案件 が地図上に表示され，これを選択すると詳細情報を 閲覧できることを示す。

（3）道路占用許可申請

道路占用許可申請の実証フィールドは大阪府枚方 土木事務所, 堺市, 富田林市, 豊中市, 門真市, 羽 曳野市とし, 参加者は府市の道路部門と上下水道部 門，ユーティリティ企業である。検証期間は 2005 
道路調整案件の一覧表示

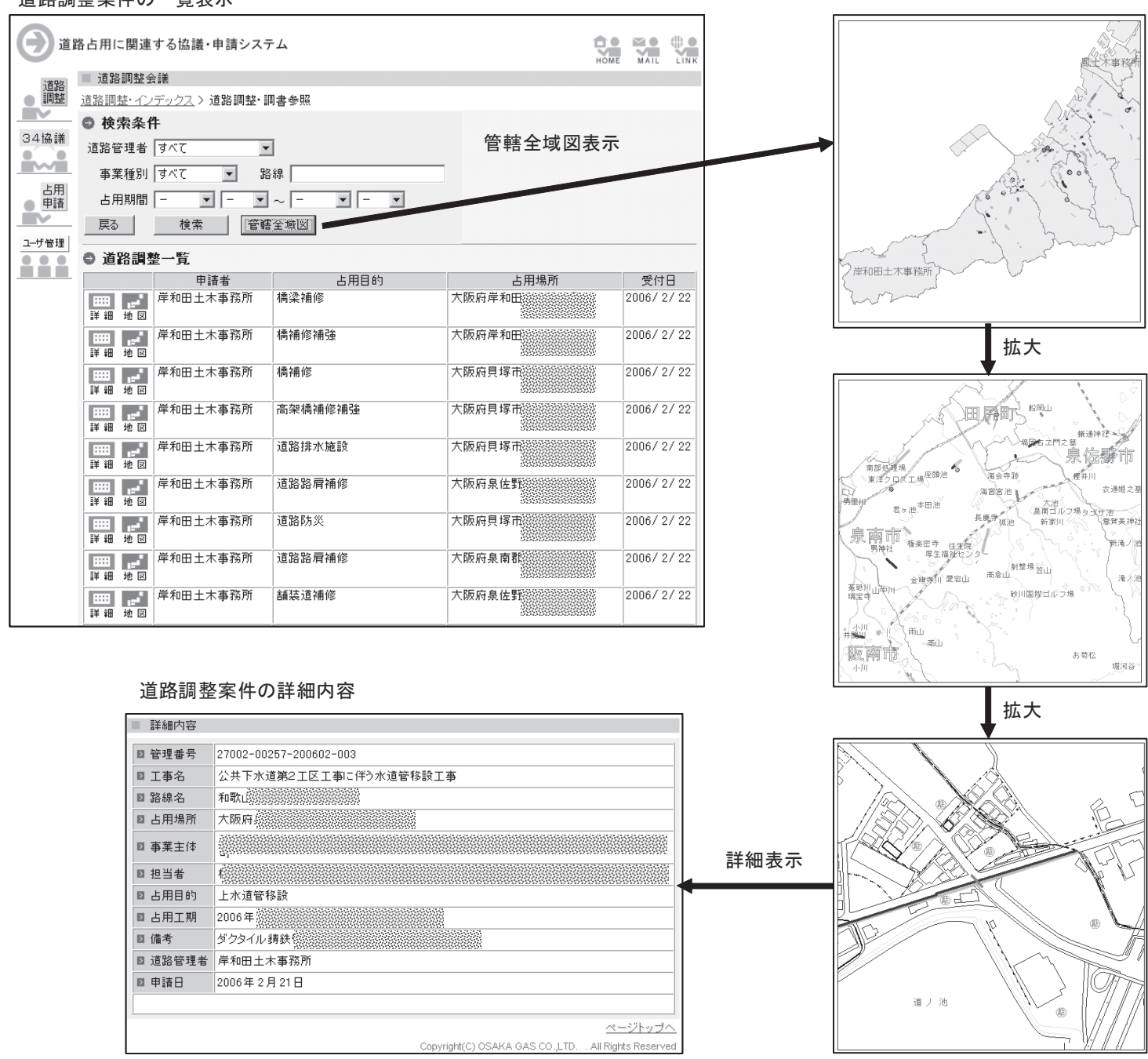

図 2 道路調整会議のシステム利用例

表 1 道路占用許可申請の件数

\begin{tabular}{c|c|c|c|c|c|c|c}
\hline 申請者 & 枚方土木事務所 & 堺市 & 富田林市 & 豊中市 & 門真市 & 羽曳野市 & 合計 \\
\hline \hline 電力 & 4 件 & 5 件 & 3 件 & 4 件 & 5 件 & 5 件 & 26 件 \\
\hline 通信 & 1 件 & 3 件 & 1 件 & 2 件 & 1 件 & 2 件 & 10 件 \\
\hline ガス & 2 件 & 5 件 & 2 件 & 1 件 & 2 件 & 3 件 & 15 件 \\
\hline 上水道 & 1 件 & 2 件 & - & - & 2 件 & - & 5 件 \\
\hline \hline 合計 & 8 件 & 15 件 & 6 件 & 7 件 & 10 件 & 10 件 & 56 件 \\
\hline
\end{tabular}

年 2 月 14 日〜 3 月 4 日である。 その結果, 表 1 に 示す 56 件の申請があった。

\subsection{2. システムに関する評価}

社会実験終了後に道路占用許可申請に係わるシス テムの操作性と有用性を評価するために, 参加者に
アンケート調查を実施した。回答者は，道路占用許 可申請の実験に参加した 6 団体, 16 名である。ア ンケート結果を図 4 に示す。その結果, 申請状況の 進渉確認（項目 4) とシステムによる業務効率化 (項 目 5）については, 約 $80 \%$ が有用と回答しており, システムの有用性を確認することができた。一方, 


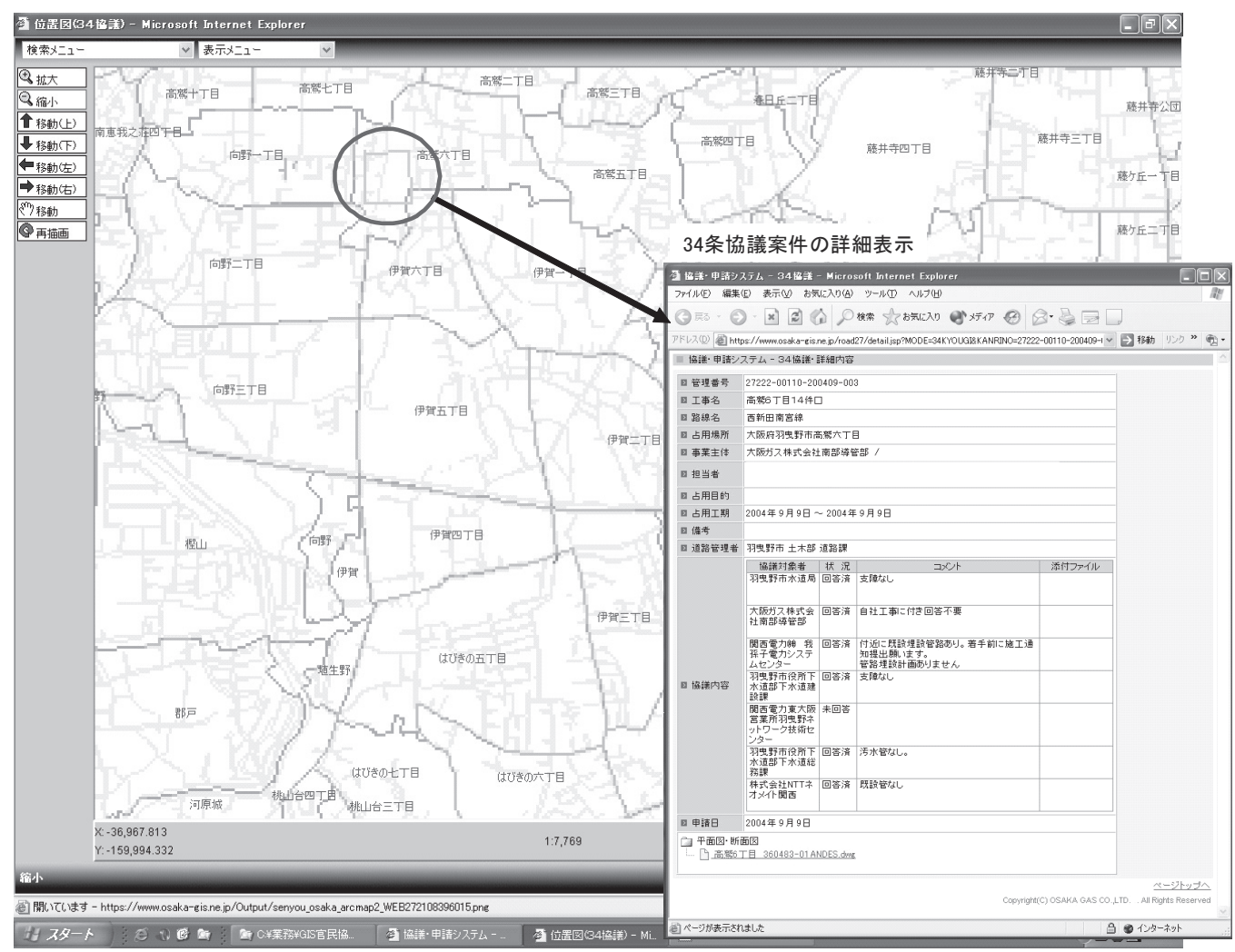

図 3 道路法 34 条協議のシステム利用例

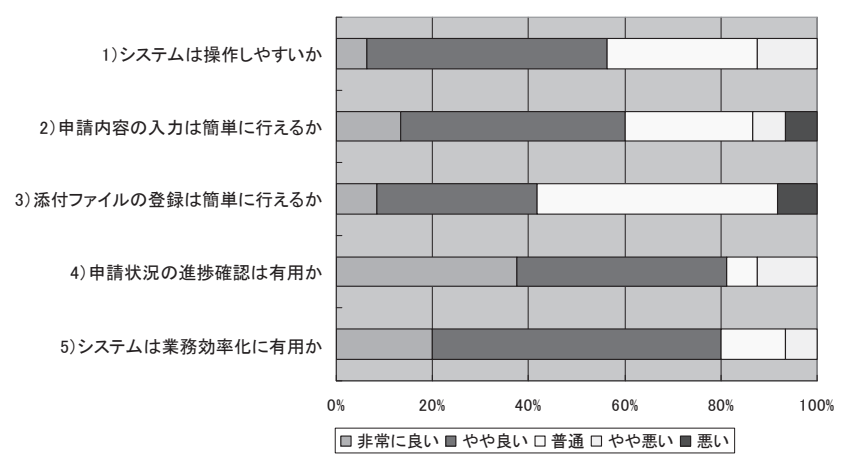

図 4 アンケート結果

システムの操作性に関する項目（1～3）について は, 肯定的な評価が $60 \%$ 以下に留まっており, 特 に添付ファイルの登録については，肯定的な評価が 約 40\% と低い. システムの操作性については, 実 験参加者がコンピュータ操作やシステムに慣れてい ないことが原因と考えられるが, 改善が必要である。

実験参加者へのアンケートとヒアリングで得られ た意見として, システムの操作性については, 申請 内容の入力は不具合なく行うことができた. ただし， 員数調書（占用物件の種類, 量, 範囲を示す調書) を Excelで作成するようにしたが，入力に時間がか
かるという問題があった。また，CAD図面の添付 を想定していたが，地方公共団体側で表示・印刷で きないことがあった. システムの有用性については, 業務効率化に関する評価を次項で述べる。

\subsection{3. 業務効率化に関する評価}

前項と同時に, 道路占用許可申請業務の効率化の 観点から道路調整会議と道路法 34 条協議ではヒア リングを，道路占用許可申請はアンケート調査とヒ アリングを実施した。なお，以下に示す意見は文意 を変えない範囲で整理したものである.

（1）道路調整会議

実験参加者にヒアリングを行い, 次の意見を得た。 ・道路調整会議の資料として十分であり，提案シス テムを利用可能である.

・道路調整会議の資料作成や移動のための時間を削 減できる。

・全体の工事位置を一括で把握でき，他事業者の工 事情報も簡単に把握できる.

・道路調整会議のみでなく, 計画工事情報を発表し, これを共有する目的で利用可能である. 新規工事 
および修繥が発生すれば，情報を追加していけば よい.

空間基盤データとシステムの活用は，官民のそれ ぞれのシステムにデータを転記する手間と会議のた めの移動時間の削減, 後工程業務におけるデー夕有 効活用に効果があると考える。従来の道路調整会議 では, 道路管理者と占用者が会議に出席し, 道路調 整会議で占用者の計画情報を収集してそれぞれの計 画情報を重㸚合わせる作業に一地方公共団体あたり 約 0.5 人月を要するとのヒアリング結果であった. 実験では，ライフラインデータの入力とその後の協 議に一地方公共団体あたり約 0.1 人月を要した。地 方公共団体の工事計画の数量による変動があるもの の, 空間基盤データを用いたライフラインデータの 共有により, 道路調整会議の省力化が可能である. 以上より, 道路調整会議の電子化は, 占用者にとっ てコスト削減，道路管理者と占用者の双方にとって 工事情報共有の有用性が高いといえる。

一方, 課題点として次の意見があった。業務でシ ステムを運用するためのルールづくりを進める必要 がある。

・システムを使いこなせるか不安であり, 紙ベース で慣れているため, 紙べースで行いたい.

・情報の入力時期によっては, 事業計画の漏洩によ る支障が懸念される。ささらに, 情報の精度や共有 化を含めたルールが必要である。

・運用ルールを整理し, 登録・変更・完工まで管理 できるように定期的な情報共有が必要である.

(2) 道路法 34 条協議

実験参加者にヒアリングを行い, 次の意見を得た ・協議のために移動を伴う施工者（占用者）にとっ ては，移動コストを削減できる，

・空間基盤データを元とする位置図を利用して工事 箇所を事前に確認できるので，有用である.

・協議回答者の観点から, 容易に回答できる工事物 件であれば対面の協議を行わず本システムで行え る.

ヒアリング結果より, 現状では申請者は複数の事 業所を移動して協議するため, 一件あたり $0.5 〜 1$ 日の作業時間が発生する。大阪府内の道路占用許可
申請数は約 26,000 件 / 年ある. そのうち, 本システ ムのみで実施できるものとして, 掘削延長が $20 \mathrm{~m}$ 以下の管路新設・撤去工事や家庭用引き込み管の新 設・撤去工事など小規模で簡易な工事 2,600 件を対 象と仮定すると, 空間基盤データ上でライフライン データを交換することにより 1,300 人日以上の作業 を削減することができる, 以上より, 道路法 34 条 協議の電子化は, 占用者が各企業体を移動するコス トの削減に効果があることがわかった.

一方, 課題点として次の意見があった，施工者と 回答者が協議を円滑に行えるように，システムで実 現できる機能を活かしたルールが求められる.

・回答者にとっては, 時間・コスト面でのメリット はあまりない.

·3 条協議の解勫が地方公共団体・ユーティリティ 企業で異なるため, システム化の前に業務プロセ スを見直すことが必要である。

（3）道路占用許可申請

アンケート結果は, 図 4 の項目 5 に示したもので ある、実験参加者にヒアリングを行い, 次の意見を 得た。

・ 申請書の提出に伴う移動時間の効率化を図ること ができるので, システムの処理速度や操作の流れ などを改善すれば大変良いシステムになり大いに 期待できる。

・道路管理者としては, 共有の空間基盤デー夕上の 占用物件デー夕を既存システムに移行できるの で，実用できればメリットがある。

道路法 34 条協議と同様に, 一件あたり $0.5 \sim 1$ 人日の申請作業に対して 2,600 件の電子申請が可能 であるとすると， 1,300 人日以上のコストを削減で きる，道路占用許可申請の電子化は，インターネッ トによる電子申請と空間基盤データを用いた GIS の機能により業務の効率化に効果があるといえる. 占用事業者にとって地方公共団体毎に手続きが変更 されることは大きな負担であるが, 手続きをある程 度標準化することができれば作業の軽減を図ること ができる。

一方, 課題点として次の意見があった.

・システムと紙による申請の併用となれば効率的で 
はないので, 簡易な工事などシステムの対象範囲 を明確にする必要がある。

・一度に大量の申請が必要なことがあり, 申請用 CAD 図面を作成し登録するよりも測量委託する 方が効率的な場合がある.

\subsection{4. 考察}

道路占用許可申請に係わるシステムの開発と評価 を通じての考察をシステムの操作性, 業務の効率化, 運用性の 3 つの観点から述べる.

\section{(1) システムの操作性}

システムの仕組みや操作性としては全体的に使い やすいとの評価が多かった。 また，申請内容と許可 状況を確認できる機能の評価が高かった。ただし， 員数調書の作成に戸惑うユーザが多かった．MSExcel を利用して新たに員数調書を作成する必要が あり, 操作に不慣れなため手間がかかるという問題 があった. 員数調書の内容は各地方公共団体によっ て異なるため, 占用物件別の統一様式や占用者毎の 様式で入力できるようにするという解決を検討する 必要がある。あるいは, 現実解として, 行政毎の様 式を利用できるようにすることも検討に值するだろ う.

\section{（2）業務の効率化}

社会実験におけるアンケートとヒアリングより， 道路調整会議, 道路法 34 条協議, 道路占用許可申 請の全てにおいて, 特に協議・申請における移動コ ストを削減でき，業務を効率化できるという結果で あった。 システムを共有の空間基盤デー夕上で利用 することにより, 地下埋設物データの交換・共有に 効果が高いことが明らかになった。ただし, 本研究 の効果算定はヒアリングを基礎として行っており， 実務でのシステム利用によってより正確な作業軽減 量を算出することが必要である.

本稼働後しばらくは紙媒体での業務と並行して実 施することとなるため, 地方公共団体側には負荷が 大きくなることが想定される，システム利用におい て, 占用者も含めた利用者の負担を小さくし効果を 発揮するために, システムの対象範囲を明確にして 運用することが必要である。
また，道路占用許可の継続申請時に複数箇所を対 象とする場合, システムでは申請者が複数の図面を 作成・入力する時間を多大に要する．システム機能 で複数箇所につき一枚の図面入力を可能にするな ど, システム操作に係る時間を短縮することが必要 である.

（3）運用性

道路占用許可申請に係わる業務は道路法に基づい ており, 他地域でも業務は同様の流れで行われる. 空間基盤データとして利用できる地理空間情報は, 地方公共団体の共用空間データや国土地理院の基盤 地図情報などが整備されている。したがって，本シ ステムを他地域で利用できる可能性は高いと考え る。また, 地方公共団体の取り扱う申請業務には, 土地開発の許可申請や建築確認申請など位置図を必 要とするものが多い. Web ベースで空間基盤デー 夕を共有し, CAD デー夕を利用可能である本シス テムの考え方は, これらの電子申請システムでも活 用できる.

システムを実験フィールドにおいて評価した結 果, 多くの事業者が参加するため運用ルールを設定 することが必要であるとの意見が多く出された：シ ステムの実運用に向けて, 以下の課題を解決するこ とが必要である。

・道路占用許可申請に係わるシステムと地方公共団 体・ユーティリティ企業の占用物または地下埋設 物管理システムに扔いて, 標準化したライフライ ンデータを円滑に連携できるようにする，地方公 共団体は, 本システムとは別の庁内バックオフィ スシステムにおいて占用許可書を作成し発行する ことが多い，従来まで，地方公共団体担当者が申 請者に許可書を紙媒体で渡していたが，これを本 システムに添付あるいは転記して内容を通知する 仕組みが必要である。

・複数事業者がシステムを利用するためにセキュリ ティを確保する。運用においては，SSLによる端 末認証などの対策を実施する，道路法 34 条協議 と道路占用許可申請には大規模ユーティリティ企 業だけではなく, 地元の水道業者が参加する可能 性がある。ここではネットワーク環境が不充分で 
あることやシステム操作に不慣れであることが考 えられるため, より広い利用者を前提として, シ ステム改善を図ることが望ましい。

・申請業務におけるワークフローを遅滞なく処理す るために, 実施可能な工事の規模, 対象物件到着 時の処理方法などの運用ルールを決める必要があ る.

\section{4. 道路占用継続の効率化提案}

道路占用継続は, 道路占用物件の許可期間が終了 し占用を継続する場合, 占用者が占用許可の更新を 受けるものである. 占用継続の手続きは現存する全 ての占用物件に必要であり, 現状では紙媒体により 処理しているため, 占用者と道路管理者の官民双方 に扔いて多大な手間となっている。

\section{1. 提案方法}

従来までの占用継続では, 過年度の道路占用許可 員数に当該年度の道路占用許可申請された占用数量 を加算することで占用物件延長を算出していた。 こ れは, 道路占用許可を管理する庁内システムや紙媒 体で行われていた。つまり, 道路管理者が有する申 請時の情報のみで占用物件延長が求められ, 施工後 の実延長が反映されていないと考えられる.

本研究では, 道路管理者と占用者が共有する空間 基盤デー夕をべースに，電子化した占用物件デー夕 を受け渡すことにより, 占用物件数量と占用料の計 算を効率化する。提案する占用継続の作業フローを 図 5 に示す。まず, 占用者のデー夕は広域であるた め, 市区町村境界により占用物件デー夕を抽出する. 道路占用継続の対象は認定道路と法定外公共物内の 占用物件であるため, これを抽出する. 次に, 認定 道路と法定外公共物内にある占用物件デー夕を抽出 する.これが占用継続の対象として占用料が発生す るものである。 そして, 抽出されたデー夕の延長を 計算し, 集計して員数調書を作成する. 継続申請が 必要な範囲は管理道路部分であるので, 本研究の提 案では, 空間基盤データの道路ポリゴンを用いて占 用物件の抽出と数量の集計を行うことができる.

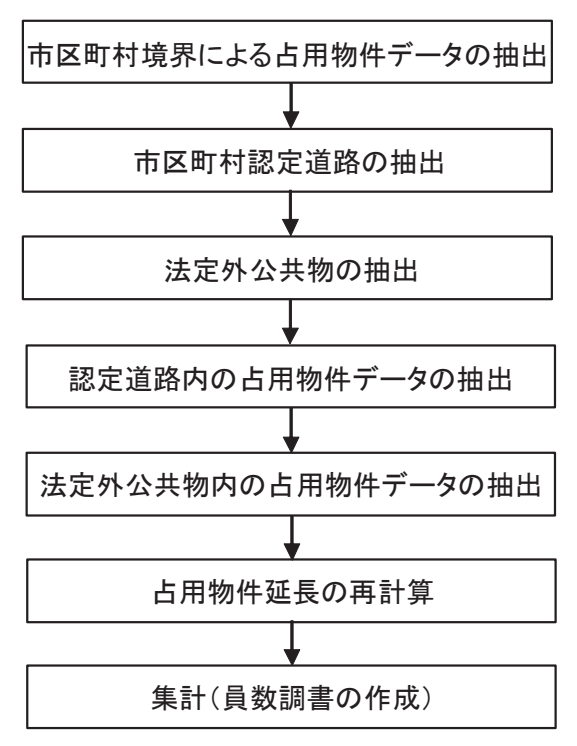

図 5 占用継続の作業フロー

\section{2. 実証実験}

4.2.1. 概要

道路管理者（行政）と占用者（ユーティリティ企 業)で別々に管理されてきた占用物件数量の差異を 明らかにし, 数量抽出の時期および申請単位の数量 の扱いに関するルール, および, 占用継続申請業務 の実状に合わせた業務ルールを確立するために，実 証実験を行った。実験では, 大阪府門真市をフィー ルドとして，ガス管の実データを利用した。なお， 空間基盤データの共有には至っていないため, 官民 それぞれの空間基盤デー夕上で整備されたデー夕を 利用した。ここでは, 道路管理者の保有する道路ポ リゴンを利用した占用物件数量の空間検索による抽 出を実施した。 そして, 抽出した占用物件数量・占 用料と申請の積み上げによる数量 - 占用料との比較 を行った，また，道路管理者においても同様の作業 を行った。

\subsection{2. 実験内容}

(1) 提供デー夕

門真市の道路管理システムで利用している道路ポ リゴンデータを Shape 形式でユーティリティ企業に 提供した。

\section{（2）ガス管データの抽出}

ユーティリティ企業では, 道路ポリゴンデータを 元に，ガス管のクリップ処理を行うためのポリゴン 


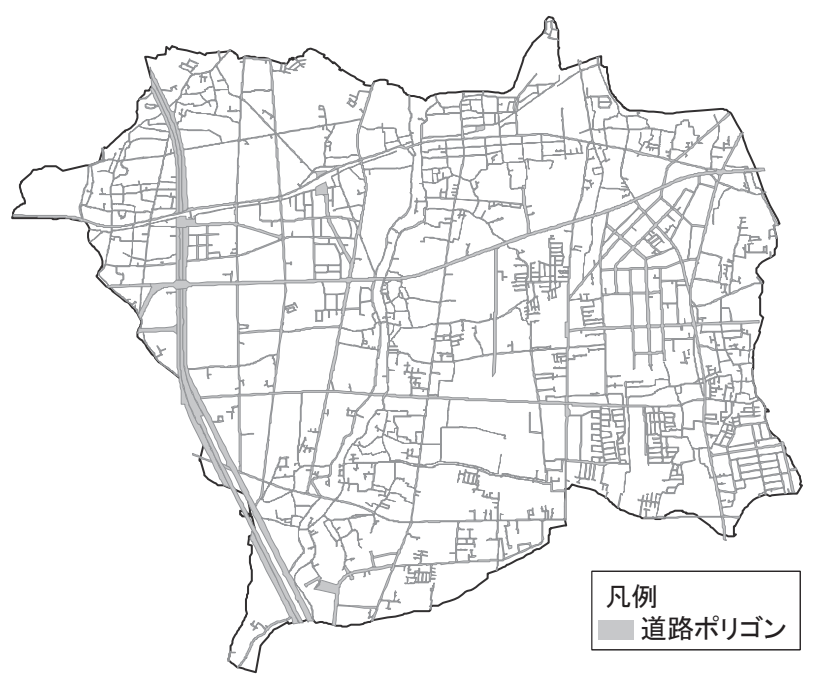

図 6 道路ポリゴンデータの抽出結果

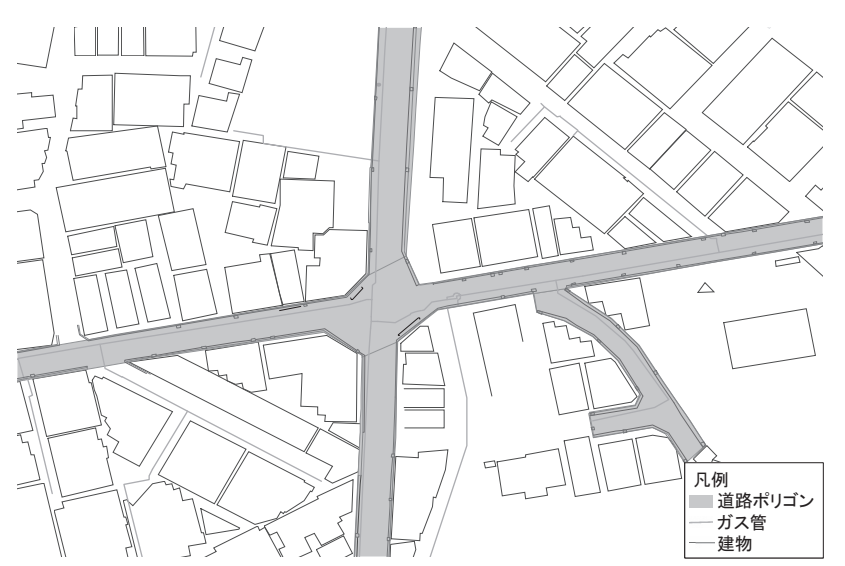

図 7 ガス管データの抽出

データを作成した。データ作成には，ESRI 社製の ArcView を利用した，ガス管データの抽出にあたっ ては，以下の点に留意する必要があった。

・法定外公共物デー夕を抽出するため, 門真市の譲 与申請コードや所有者コードなどを利用した。法 定外公共物の対象となる占用物件は, 市道以外の 部分であるため, 法定外公共物デー夕を市道ポリ ゴンデータによってクリッピング処理した。

・市道データには, 府道および国道との交差点が整 備されているため，これらのデータを削除する作 業を行った。

ガス管データの抽出に使用する道路ポリゴンデー タとして, 図 5 に打ける「市認定道路の抽出」と「法 定外公共物の抽出」を行った結果を図 6 に示す。こ の道路ポリゴンデータを利用して, 空間検索によっ
て占用物件（ガス管）データを抽出した結果を図 7 に示す.

\subsection{3. 占用継続数量の検証}

抽出したガス管デー夕延長を算出し，これと当該 年度の占用許可申請による員数を比較して, 抽出 データを検証した。比較結果を表 2 に示す，表中で 既存の道路占用許可員数には管径 $1.0 \mathrm{~m}$ 以上の占用 物が $116 \mathrm{~m}$ 存在している. 門真市ではガス設備のバ ルブやガバナを管径 $1.0 \mathrm{~m}$ 以上の管路と見なし，一 個あたり $1.0 \mathrm{~m}$ の延長として計算しているため, ガ ス管データでは人孔とハンドホールとして分類され ている設備数を集計して 116 箇所 $\times 1 \mathrm{~m}$ を補正した。 管径 $0.1 \mathrm{~m}$ 未満の集計差は約 $-2,400 \mathrm{~m}$ であるが, $0.2 \mathrm{~m}$ 以上 $0.4 \mathrm{~m}$ 未満の集計差が約 $1,178 \mathrm{~m}$ などとなり, 結 果的に総延長では約 $75 \mathrm{~m}$ の集計差となった。また, 集計差率は管径 $0.4 \mathrm{~m}$ 以上 $1.0 \mathrm{~m}$ 未満で $15.4 \%$ とな り, これ以外の管径との相殺により, 総延長での数 量の差は結果的に $0.1 \%$ 未満となった。管径の規模 によって数量の増減が生じているのは, 既存の道路 占用許可員数は道路占用許可申請時点の占用延長を 積み重ねた結果であるが, 申請後の工事現場の状況 によって発生した変更が GIS デー夕には反映され, 最新の情報に更新されているためと考えられる。申 請延長の積み重ねと GIS による抽出結果のずれは, 門真市だけでなく他市町村でも同様に発生すると考 えられる. 既存の道路占用許可員数と GIS デー夕 
表 2 既存の道路占用許可員数と GIS の集計結果

\begin{tabular}{|c|c|c|c|c|}
\hline 管径 & 道路占用許可員数 (m) & GIS の集計結果 (m) & 集計差 $(\mathrm{m})$ & 集計差率 (\%) \\
\hline $0.1 \mathrm{~m}$ 未満（都市ガス） & $62,404.15$ & \multirow{2}{*}{$60,354.16$} & \multirow{2}{*}{$-2,395.09$} & \multirow{2}{*}{-3.8} \\
\hline $0.1 \mathrm{~m}$ 未満（LP ガス） & 345.10 & & & \\
\hline $0.1 \mathrm{~m}$ 以上 $0.15 \mathrm{~m}$ 未満 & $3,623.20$ & $3,771.75$ & 148.55 & 4.1 \\
\hline $0.15 \mathrm{~m}$ 以上 $0.2 \mathrm{~m}$ 未満 & $30,445.95$ & $31,247.47$ & 801.52 & 2.6 \\
\hline $0.2 \mathrm{~m}$ 以上 $0.4 \mathrm{~m}$ 未満 & $27,406.15$ & $28,584.37$ & $1,178.22$ & 4.3 \\
\hline $0.4 \mathrm{~m}$ 以上 $1.0 \mathrm{~m}$ 末満 & $2,223.30$ & $2,566.47$ & 343.17 & 15.4 \\
\hline $1.0 \mathrm{~m}$ 以上 & 116.00 & 0.98 & \multirow{2}{*}{-0.98} & \multirow{2}{*}{-0.8} \\
\hline 人孔・ハンドホール類 116 箇所 $\times 1 \mathrm{~m}$ の補正 & - & 116.00 & & \\
\hline $\begin{array}{c}\text { 総延長 } \\
\end{array}$ & $126,563.85$ & $126,641.20$ & 75.39 & 0.1 \\
\hline
\end{tabular}

の検証を積み重ねていくことが必要であろう。ただ し，GISによる集計結果から占用料を集計したとこ 万, 既存の道路占用許可員数との金額の差は約 $1 \%$ であり，GISによる集計結果を使って占用数量の集 計を行える可能性が高いことがわかった．

\section{3. 考察}

実証実験により，空間基盤デー夕上で地下埋設物 データと道路ポリゴンデー夕を共有することによっ て，管路データの編集と員数表の作成のみで道路占 用継続作業を完了することができるため, 印刷や電 子媒体でのデー夕交換の作業を削減でき，コストを 削減できることを示した。ただし，運用においては， 以下の課題があると考える.

・市の道路データだけでなく, 府道, 国道, 隣接市 道においても同様の処理を実施できるように，道 路デー夕の精度を向上させる必要がある.

・空間基盤デー夕における市道と府道, 国道との交 差部が不明確な場合の取り扱いを決定する必要が ある。

・道路ポリゴンと法定外ポリゴンは, 集計作業を正 確に実施するために正確なポリゴンデータである ことが求められる.

\section{4. 実運用}

本研究で提案した方法による道路占用継続の申請 は, 門真市と大阪ガスによって 2006 年度より実運 用されている。第 1 回目の占用継続デー夕受け渡し は，2006年 6 月に実施された。そこでは，門真市 が 2006 年 3 月末時点の認定道路および法定外公共
物のポリゴンデータを大阪ガスに提供した。本稿執 筆時までに 4 年（2006 2009 年度）のデー夕を対 象に，提案方法による道路占用継続申請が毎年行わ れ，官民双方の業務に欠かせないものとなっている.

4.2.3. で述べたように市で積み上げた道路占 用許可員数と GIS データとの誤差の課題があるが, 他市においても本提案の方法で道路占用継続業務の 効率化に取り組み始めており，本提案を広く展開で きる有用性が示されている。本研究ではガス管デー 夕を対象としたが，本提案は空間基盤デー夕を共有 することにより他の地下埋設物デー夕にも適用可能 である。

\section{5.おわりに}

本研究では, 道路占用物（特に地下埋設物）の管 理業務を対象として, 協議・申請に係る業務効率化 と情報共有の課題を解決するために，官民共有の空 間基盤デー夕を活用した協議・申請システムの開発 と検証を行った。まず，道路占用許可申請業務の電 子化を実現するために，空間基盤データを利用した 情報システムを開発した。システムでは，WebGIS によって占用許可申請に必要な位置図が作成され， 申請書や図面を添付される。システムの操作性と有 用性を検証するために，地方公共団体と占用者を対 象に実証実験を行った。その結果，システムの操作 性に課題があるものの, 協議・申請に係る移動コス 卜を削減できること，拉よび地下埋設物情報を地方 公共団体と占用者で迅速に共有できることが有用で あると示された，情報共有により，地下埋設物の管 理を正確に行うことと申請に添付される $\mathrm{CAD}$ 図面 
を用いて空間基盤デー夕を更新するという展開が考 えられる。

次に, 道路占用許可申請業務の一連の流れを支援 するために, 道路占用物件の継続申請業務の効率化 を実現する方法を提案した. そこでは, 空間基盤デー 夕を用いて占用物件デー夕を抽出し, 地方公共団体 とユーティリティ企業で交換する方法を提案した. そして, 大阪府門真市において実デー夕による実証 実験を行い, 提案方法の有効性を検証した。提案方 法は 2006 年度から実運用されており, 占用継続申 請の効率化を実現している.

今後は, 道路占用許可申請システムの実用化と道 路占用継続へのより多くの地方公共団体の参加を実 現するために, 普及活動を推進するとともに, 交換 データや属性データの形式, 運用ルールを策定する 予定である。

\section{謝辞}

本研究を遂行するにあたり, GIS 大縮尺空間デー 夕官民共有化推進協議会に参加している大阪府, 府 内市町村， ユーティリティ企業の各位に御協力いた だいた。ここに記して感謝の意を表する。

\section{参考文献}

窪田諭，山内徹，柗村一保（2005）官民協働による 道路管理に係わる協議・申請システムの開発と検証, 土木情報利用技術論文集, 土木学会, 14, 211-218.
窪田諭, 㫟村一保, 梶川正純, 碓井照子, 吉川眞 (2007) 空間基盤データの整備と利活用における官民協働の 実証研究，土木学会論文集 D, 64(4)，464-477.

佐藤裕人（2002）GIS 活用オンライン道路占用許可 申請システム, GITA-Japan 第 14 回コンファレンス 資料。

東明佐久良 (2008) 施設管理・ライフラインと GIS.（村山祐司・柴崎亮介 編), 『ビジネス・行政 のための GIS』，朝倉書店，73-85.

総務省自治行政局地域政策課地域情報政策室, 地方 自治情報センター研究開発部，東京大学空間情報科 学研究センター（2009）地理空間情報に関する地域 共同整備推進ガイドライン.

国土交通省（2003）地方公共団体に打ける道路占用 許可電子申請システムの基本仕様.

国土交通省（2005）道路台帳管理デー夕製品仕様書 ( 素案).

馬渡五郎（2006）地理空間情報としての道路管理シ ステムとこれからの課題, GITA-Japan 第 17 回コン ファレンス資料.

（2009年 10 月 8 日原稿受理， 2010 年 4 月 9 日採用 決定, 2010 年 6 月 3 日デジタルライブラリ掲載) 